\title{
Fluctuations of winter wheat yields in relation to length of winter in Sweden 1866 to 2006
}

\author{
Björn Holmer* \\ Physical Geography, Department of Earth Sciences, Göteborg University, Box 460, 40530 Göteborg, Sweden
}

\begin{abstract}
The winter wheat Triticum aestivum L. areas in Sweden (55 to $61^{\circ} \mathrm{N}$ ) are at, or close to, the northern border of winter wheat cultivation. Yield variations at the county level for 1866 to 2006 are analysed and compared with variations in length of winter. Yield deviations greater than $\pm 25 \%$ occur on average once every $5 \mathrm{yr}$ in a county, but more often in the north. In a maritime climate such as the one in north-western Europe, the length of winter fluctuates considerably. Deviations in length of winter by more than $\pm 45 \mathrm{~d}$ appear on average once every $5 \mathrm{yr}$ in a county, but more frequently in the southern coastal counties. However, freezing temperatures are also more intermittent there compared to the continuous cold in the north. By means of a cluster analysis of the variations in length of winter, the counties were divided into 4 groups. The general effect is that long winters give decreasing yields. Regressions between deviations in yield and length of winter show determination coefficients $\left(\mathrm{R}^{2}\right)$ in the range of 0.13 to 0.30 , which is high for a single variable. Winters are, on average, $48 \mathrm{~d}$ longer when yields are $25 \%$ below trend compared with yields $25 \%$ above trend. This pattern seems to be typical for climates with winter temperatures $<5$ to $6^{\circ} \mathrm{C}$.
\end{abstract}

KEY WORDS: Length of winter $\cdot$ Winter wheat yield $\cdot$ High latitude $\cdot$ Climate fluctuations

\section{INTRODUCTION}

The winter wheat Triticum aestivum areas in Sweden $\left(55\right.$ to $\left.61^{\circ} \mathrm{N}\right)$ are at, or close to, the northern border of winter wheat cultivation. Yields are high (average over $6000 \mathrm{~kg} \mathrm{ha}^{-1}$ ). However, there is a considerable variability both within the country and between different years. Four circumstances make a maritime climate such as that of northwestern Europe especially sensitive to impacts on agriculture. First, the area is at the northern frontier of the successful growing of cereals. Second, cool summers and mild winters result in a temperature distribution with small differences between consecutive months. Thus, a slight change of temperature, especially during the winter, results in a large deviation in the length of winter and the vegetation period, while the same change of temperature has little effect in a more continental climate (Bourke \& Rosini 1985). Third, in a maritime climate, there is a steep lapse rate in the lowest part of the troposphere
(Ångström 1938, Laaksonen 1976, Harding 1978, Harding \& Green 1980, Trewartha 1982). As a consequence, vast upland areas may be unsuitable to cultivation through cooling or suitable if there is warming. Fourth, the climate in northwestern Europe is characterised by an alternation of cyclones and blocking highs (Lejenäs 1985, Stein 2000, Fournier 2003), which, especially in winter, means very differing temperatures due to the different source areas of the air masses involved.

Winter wheat Triticum aestivum is primarily grown in temperate areas, since a cool season is necessary for the vernalization process, i.e. a certain amount of cold is required to reduce the number of leaves and initiate an early anthesis. The optimum temperature seems to be 5 to $6^{\circ} \mathrm{C}$ (Rawson et al. 1998, Porter \& Gawith 1999, Yan \& Hunt 1999), whereas the time necessary for vernalization increases for temperatures below optimum (Rawson et al. 1998). The process is further complicated by intermittent low temperature regimes (Robertson et al. 1996), day length (Brooking \& Jamieson 
2002) and photoeffects beyond the end of the vegetative phase (Gonzalez et al. 2002).

Very cold winters cause winter kill of seedlings. Temperatures of -20 to $-15^{\circ} \mathrm{C}$ are lethal (Porter \& Gawith 1999). However, snow cover gives protection, acting as an insulation layer. For example, with $10 \mathrm{~cm}$ of snow, the nighttime soil temperature minimum can be as high as $-12^{\circ} \mathrm{C}$, while the air temperature minimum is $-30^{\circ} \mathrm{C}$ (Peel \& Riveland 1997).

Data on winter wheat yields in southern England for $>100$ yr (Chmielewski \& Potts 1995) showed negative correlation with precipitation occurring in all months, i.e. there is more than enough water for the entire year. Negative temperature correlations also prevailed for most of the year, especially in July, which means that high temperatures were not favourable to yields. A significantly high correlation with maximum temperature in April was a notable exception, showing that higher temperatures in spring will encourage plant development after the winter. Landau et al. $(1998,2000)$, using more recent yield data from the entire UK, supported the adverse effect of precipitation and minimum temperature in July, but stressed the positive correlation with maximum temperature in January and diminished winter killing due to a fewer number of extreme frosts. Similarly, Olesen et al. (2000), in Denmark, showed a positive effect of a high temperature in October, November and January and a strong negative effect of too much precipitation in July. On the other hand, Alexandrov \& Hoogenboom (2001) noticed positive yield effects caused by low winter temperatures in the much warmer region of Georgia in the United States. In a study of winter-time empirical orthogonal function (EOF) decomposition of the $500 \mathrm{hPa}$ geopotential height fields, Cantelaube et al. (2004) found a strong positive correlation between the first principal component (PC) (similar to the North Atlantic Oscillation) and December to March temperature in southern Scandinavia, and also a strong positive correlation between winter wheat yield and PC1. Finally, it can be noted that, in Sweden, Enquist (1929) found that years with high yields were preceded by short, mild winters and low yields by long, cold winters.

The commercial growth of winter wheat is only found in the southern half (55 to $61^{\circ} \mathrm{N}$ ) of Sweden, in the Counties B to X (letters B to X are the official abbreviations for these counties; Fig. 1). Counties M, E and $\mathrm{R}$ have the largest areas of wheat cultivation. Little wheat is grown in the counties at the northern fringe (W and X) and in the counties on the South Swedish Uplands ( $F$ and $G$ ).

During the late 19th century rye was the main cereal. Wheat was considered a demanding crop and was only cultivated on the best soils (Lägnert 1949). Developments such as new varieties, increased use of fertilis-

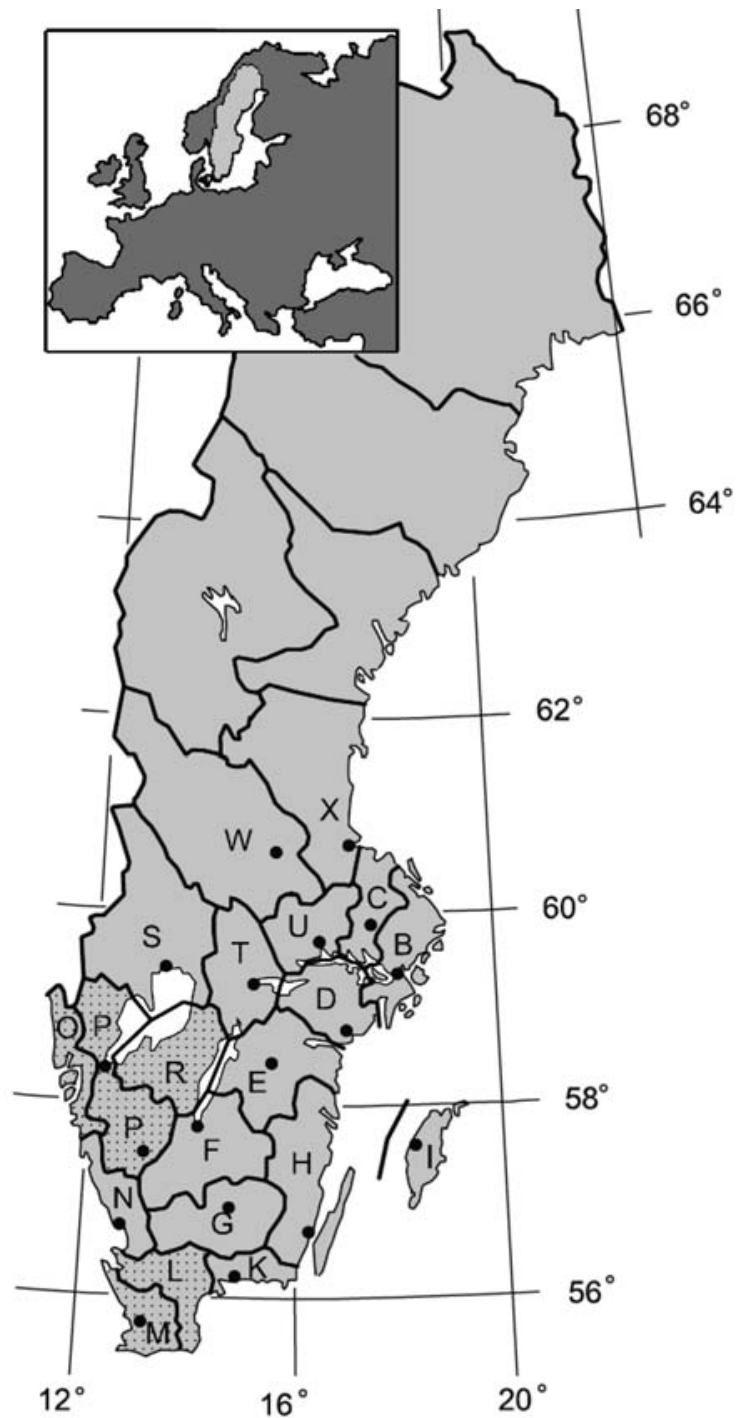

Fig. 1. Counties (B to X) with winter wheat cultivation and climatological stations (names in Table 1). The dot-hatched areas show the 2 new larger merged counties created in the 1990s

ers, ditching, etc. led to an increase in the wheatgrowing area, which continues today, while, on the other hand, the total area under cultivation reached a maximum during the 1930s. Another important aspect is that the rationalisation of Swedish agriculture, especially during the last few decades, has resulted in a considerable concentration to the best soil. Counties E, $\mathrm{M}$ and $\mathrm{O}$ have the largest wheat areas, followed by Counties C and D. Together these counties stand for $75 \%$ of the wheat cultivation in Sweden.

In spite of its high latitude, southern Sweden does not have particularly cold winters: on average (1961 to 1990), $\pm 0^{\circ} \mathrm{C}$ in the southernmost part to $-6^{\circ} \mathrm{C}$ in the northern parts of the winter wheat cultivation area (Raab \& Vedin 1995). However, the variability is large; in the south, the January average is below $-4^{\circ} \mathrm{C}$ in $1 \mathrm{yr}$ 
in 10 , but it also exceeds $+3^{\circ} \mathrm{C}$ in $1 \mathrm{yr}$ in 10 . In the north, the corresponding temperatures are -11 and $-1^{\circ} \mathrm{C}$, respectively. Air temperatures can go down to $-20^{\circ} \mathrm{C}$ along the southwestern coast and to $-35^{\circ} \mathrm{C}$ in the uplands and in the north. Summer temperatures vary little, averaging from $15^{\circ} \mathrm{C}$ in the higher parts to $17^{\circ} \mathrm{C}$ in areas closer to sea level. Thus, altitude rather than latitude is most important to summer temperatures. Precipitation is fairly evenly distributed over the year with a summer maximum. The western half of southern Sweden is wetter ( 700 to $1000 \mathrm{~mm} \mathrm{yr}^{-1}$ ) than the eastern half ( 500 to $700 \mathrm{~mm} \mathrm{yr}^{-1}$ ). Snow depths in February, which is generally the time for maximum snow depth in southern Sweden, are, on average, $<10 \mathrm{~cm}$ along the southern coasts; in fact, half of the years lack snow. In the uplands and in the northern part of the wheat cultivation area snow depth is $\sim 30 \mathrm{~cm}$.

Thus, as shown above, the temperature conditions during the winter have proved to be important to vernalization and yield of winter wheat, and winter conditions also vary temporally and geographically in the south of Sweden. A long winter is not necessarily a cold winter, and a winter with low air temperatures does not necessarily have low soil temperatures, since a thick snow cover can insulate the ground. However, in the present study, the length of winter is used to characterise the winter climate, because this is a measure that can easily be obtained from common monthly temperature data.

The purpose of this study was to investigate the influence of length of winter on winter wheat yield in different counties of Sweden from 1866 to 2006. Considering that the northern limit for cultivation of winter wheat passes through Sweden, variations in the length of winter can be hypothesized to be important to yields. Since yields have increased considerably due to non-climatic factors (e.g. genetic improvements, fertilisers, drainage, farming achievements, the closing down of farms on poor soils), percentage deviations from yield trends will be studied. No special consideration has been given to the fact that the varieties of winter wheat used in Sweden have changed temporally and geographically. In each county a meteorological station was chosen to characterise the winter climatology. Also, the climate has changed, so in order to study the impact of the variability in length of winter the trends in length of winter have been removed.

Specific questions addressed by the present study include: (1) What are the spatial patterns and temporal frequencies of large deviations in the length of winter in Sweden? (2) What are the spatial patterns and temporal frequencies of large deviations in winter wheat yields in Sweden? And (3) what are the spatial and temporal relationships between yield deviations and winter length deviations in Sweden?

\section{DATA AND METHODS}

\subsection{Climate}

Twenty stations (1 in each county; Table 1) were chosen for analysis. Data are found in tables from the Swedish Meteorological and Hydrological Institute and its various predecessors. All stations have been altered in some way during the $140 \mathrm{yr}$ period used in this study. Sometimes, as in the cases of Stockholm and Uppsala, these are small changes in the geographical location and altitude of the thermometer (Moberg \& Bergström 1997). In some cases the station has been moved to an airfield outside the town, for example, Jönköping, Linköping, Visby and Västerås. In addition, even if the station has not been moved, the builtup area may have increased, and thus it exhibits the urban heat island effect. Station Nyköping in County D was closed down in 1979, and there is no longer a station in this county with a temperature record that is long enough. However, Station Linköping in County E has been found to have a close 1:1 relation with Nyköping (average difference in length of winter is $1 \mathrm{~d}$ or less), with a coefficient of determination of 0.92 , so Linköping is also used for County D.

The methods used to obtain average temperatures have changed several times. Before 1914, 3 observations per day were used according to a formula by Edlund, but later the calculations also included coeffi-

Table 1. Data overview

\begin{tabular}{|lclc|}
\hline County & Yield data & Station & Meteorol. data \\
\hline B & $1866-2006$ & Stockholm & $1866-2006$ \\
C & $1866-2006$ & Uppsala & $1866-2006$ \\
D & $1866-2006$ & Nyköping & $1874-1979$ \\
E & $1866-2006$ & Linköping & $1866-2006$ \\
F & $1866-1984$ & Jönköping & $1866-2006$ \\
G & $1866-1967$ & Växjö & $1866-2006$ \\
H & $1866-2006$ & Kalmar & $1866-2006$ \\
I & $1866-2006$ & Visby & $1866-2006$ \\
K & $1866-2006$ & Karlshamn & $1866-2006$ \\
L & $1866-1996$ & Kristianstad & $1879-2006$ \\
M & $1866-1996$, & Lund & $1866-2006$ \\
& $1997-2006^{\text {a }}$ & & \\
N & $1866-2006$ & Halmstad & $1866-2006$ \\
O & $1866-1997$, & Göteborg & $1866-2006$ \\
& $1998-2006^{\text {b }}$ & & \\
P & $1869-1997$ & Vänersborg & $1866-2006$ \\
R & $1866-1997$ & Skara & $1866-2006$ \\
S & $1866-2006$ & Karlstad & $1868-2006$ \\
T & $1866-2006$ & Örebro & $1866-2006$ \\
U & $1866-2006$ & Västerås & $1874-2006$ \\
W & $1867-1984$ & Falun & $1866-2006$ \\
X & $1866-1977$ & Gävle & $1866-2006$ \\
a In 1997 Counties M and L merged into 1 county \\
b In 1998 Counties O, P and R merged into 1 county \\
\hline
\end{tabular}


cients based on longitude and time of the year (Ekholm 1914). Ekholm provided corrections to the Edlund formula, which in this study have been applied to the published data. Data before 1879 have also been corrected for the change from local solar time to a common time zone for all of Sweden. Thus, systematic errors due to changing practices of observation times and calculation methods can be considered small.

Length of winter can be defined as the number of days with temperatures below zero. In the present study the start and finish date of the winter are based on linear interpolation of monthly mean temperatures plotted at the middle of the month with the actual number of days in the months taken into consideration. However, there is a definition problem when, for example, November has sub-zero temperature, January and February have above zero temperatures and March, below zero temperatures. In such a case, the definition in this analysis is a winter that starts in October/November and finishes in March/April, despite the positive temperatures between the cold months.

Detrended instead of actual values of length of winter are used. Otherwise there would be a bias of winters longer than normal in the first half of the series and shorter than normal in the second half, due to ongoing climate warming. Since the wheat varieties have changed several times during the period, it is not the actual length of winter that is so important, but how the deviation in length of winter from what is expected (the trend) in a certain year will influence the current variety of winter wheat. The use of detrended data also reduces effects of changes of the station.

\subsection{Winter wheat}

Data on winter wheat Triticum aestivum yields have been excerpted from the statistical yearbooks of agriculture in Sweden in the series: 'Jordbruk och boskapsskötsel' 1866 to 1963 and 'Jordbruksstatistisk årsbok' 1965 and later ${ }^{1}$. Until 1963, the year corresponded to the year of harvest and, after then, to the year of publication, so there is no gap in 1964. The time series can be been divided into 3 parts due to the methods used by the authorities to collect data: 1866 to 1912,1913 to 1959 and 1960 to 2006. By coincidence, the 3 parts have exactly the same length.

Since the statistics were published with some years' delay, from 1874 to 1963 there was also a series called

${ }^{1}$ Agriculture et élevage du bétail 1866-1950. Farming and stock rising 1951. Agriculture 1952-1963, Statistical Yearbook of Agriculture 1965-1974, Yearbook of Agricultural Statistics 1975-2006
'Årsväxten'르, which was published during the autumn following the harvest in order to give the authorities an early survey. In these volumes preliminary data on the harvest can be found. They have been used to check some remarkable data in the final statistics. However, they are also the only source for the years 1912, 1938 and 1939, since no agricultural yearbooks were published for these years. Below is a summary of the nature of the data collected for each of the 3 major time periods in the study.

\subsubsection{6 to 1912}

Data were collected in the field by the Rural Economy and Agricultural Society in each county. There were no specific instructions on how the work should be performed. Consequently, the quality of data differs both over time and between different counties, because of different and changing ambitions both at local and regional administration levels (Höijer 1921, Lägnert 1949, Svensson 1965). Data were based on questions about harvests from different farms, especially in the most intensively cultivated areas.

Yields are not given explicitly in any column. However, it is possible to estimate yields assuming that the amount of seed on a given area tends to be $2.6 \mathrm{hl} \mathrm{ha}^{-1}$, with only small variations (Hannerberg 1971). Volumes of the winter wheat seed, $V_{\mathrm{w}}(\mathrm{in} \mathrm{hl})$, are found in the statistics, so winter wheat areas, $A_{\mathrm{w}}$ (in ha), can be obtained as:

$$
A_{\mathrm{w}}=V_{\mathrm{w}} / 2.6
$$

Harvest, $H_{\mathrm{w}}$ is given as a volume, so to calculate the yield it is necessary to use the volume weight of winter wheat, $D_{\mathrm{w}}$, which is found in a separate table in the statistics. Then, the yield (in $\mathrm{kg} \mathrm{ha}^{-1}$ ) is calculated as:

$$
\text { Yield }=H_{\mathrm{w}} / A_{\mathrm{w}} \times D_{\mathrm{w}}
$$

For the year 1912, data on the harvested volume of winter wheat, $H_{\mathrm{w}}$, and volume weight, $D_{\mathrm{w}}$, can be found in Årsväxten, but data on the amount of seed necessary to calculate $A_{\mathrm{w}}$ cannot be found. Instead, $A_{\mathrm{w}}$ is obtained as the trend of the preceding $5 \mathrm{yr}$. A complication with Årsväxten is that its data are estimates collected in the autumn before threshing. Therefore, to avoid bias, $H_{\mathrm{w}}$ was adjusted by means of the average ratio of data of harvested volumes according to Årsväxten and the statistical yearbooks for the preceding 5 yr.

The statistics on arable land before 1913 have been seriously criticised by Lägnert (1949) and Svensson

\footnotetext{
${ }^{2}$ La récolte; rapport préliminaire 1874-1950. Crops-acreage and production. Preliminary report 1951-1963
} 
(1965). They noticed that, in many cases, data at the parish level had not been changed for years in some columns and that changes often occurred in large leaps. Especially, Svensson (1965) concluded that use of the statistics on arable land gives a totally false picture of the agricultural development in the late 19th century. However, the primary yield data from the farmers were given as the ratio of harvest to seed (in Swedish 'korntal'), which is an easy and essential measurement for farmers. Total harvest was then calculated from the amount of seed. The importance of this is that estimates of yield are not particularly sensitive to the fact that data on the amount of seed are unchanged for some years.

\subsubsection{3 to 1959}

From 1913 the responsibility for agricultural statistics was taken over by the Central Bureau of Statistics, which issued instructions to the Rural Economy and Agricultural Societies on how to collect data (Medin 1999). Data were still based on questions to farmers, but yields were now calculated and printed explicitly in a special column in the statistics. In 1938 and 1939 no yearbooks were published, but the preliminary yield data in Årsväxten are available. For the present study these data were bias adjusted according to the ratios of yield data in Årsväxten and the statistical yearbooks 1932 to 1937.

To check the connection between yield data in 1866 to 1912 and in 1913 to 1959 , the linear trends of the 2 periods were calculated. On average, the difference in 1913 was $+1 \%$ and 16 of 20 counties were within $\pm 5 \%$; extremes were $-12 \%$ for County G and $+15 \%$ for County W. Thus, the methodology used to estimate yield before 1913 seems reasonable.

\subsubsection{0 to 2005}

From 1960 to 1994 yields are based on actual harvest in statistically chosen test plots. Zetterberg et al. (1953) gave an outline of the coming change. However, to reduce costs, the number of plots were cut down in 1995 and compensation questionnaires were issued to statistically selected farmers (Olofsson 1999), and, since 1998, all data have been based on the questionnaires.

Some counties with only small areas of winter wheat disappeared from the yield statistics during this period, due to the uncertainty created by the small number of test plots (Counties G and X), and, consequently, they are not used in the analysis (Table 1). Counties F and $\mathrm{W}$ disappeared for the same reason for about $15 \mathrm{yr}$, but reappeared during the last decade, so these counties are used. The statistics have also ceased for Counties $\mathrm{L}, \mathrm{M}, \mathrm{O}, \mathrm{P}$ and $\mathrm{R}$ as separate units, due to their recent merger into 2 large administrative units. Backcalculated statistics for these new counties have been created, as mean values for the old counties weighted by the yearly winter wheat areas.

Comparisons between yields from test plots and estimated yields have shown that the estimates should, on average, be $18 \%$ higher (Hannerberg 1971, p. 67, Olofsson 1999). To compensate for this bias, the yields before 1960 are increased by $18 \%$ in the present study. In 1866 to 1962 the water content was variable, but not stated; in 1963 to 1975 yields are given at $16.5 \%$ water content and from 1976 at $15 \%$. No corrections for this have been applied. However, since detrended data are used, these uncertainties in yield can be considered to have little importance.

\section{RESULTS}

\subsection{Length of winter}

All stations show that the length of winter decreases with time and that the interannual variation is large. A year with a very long winter can be followed by a year with an extremely short one (Fig. 2). However, as pointed out above, de-trended values are used in the analyses. A cluster analysis was performed in order to objectively determine the pattern of deviating winters occurring among the counties. The program package WINSTAT was utilized for the calculations according to Ward's method, with the deviations from trends from 1866 to 2006 used as input. The analysis divided the counties into 3 distinct clusters - south, central and north (Fig. 3). The pattern can easily be interpreted as the effect of increasing continental or colder winters, since the summer temperatures are fairly equal. These 3 groups of counties with different patterns of winter deviations are used below in the analyses of the winter wheat Triticum aestivum yields.

Deviations exceeding 45 d, i.e. $1.5 \mathrm{mo}$, were arbitrarily chosen for further investigation (Fig. 2). Frequencies of both short and long winters are lowest in the northern counties, while the coastal counties, I, H and $N$, have the highest frequencies (Fig. 4), thus showing a maritime influence.

Positive deviations (winters longer than trends) occur at a lower frequency than negative deviations (Table 2). Overall, there are $7.7 \%$ anomalously long winters and $11.8 \%$ short winters, i.e. about 1 winter in 5 has a length that deviates at least 1.5 mo. The frequencies of shorter winters increase with time in the north, but not in the south. 

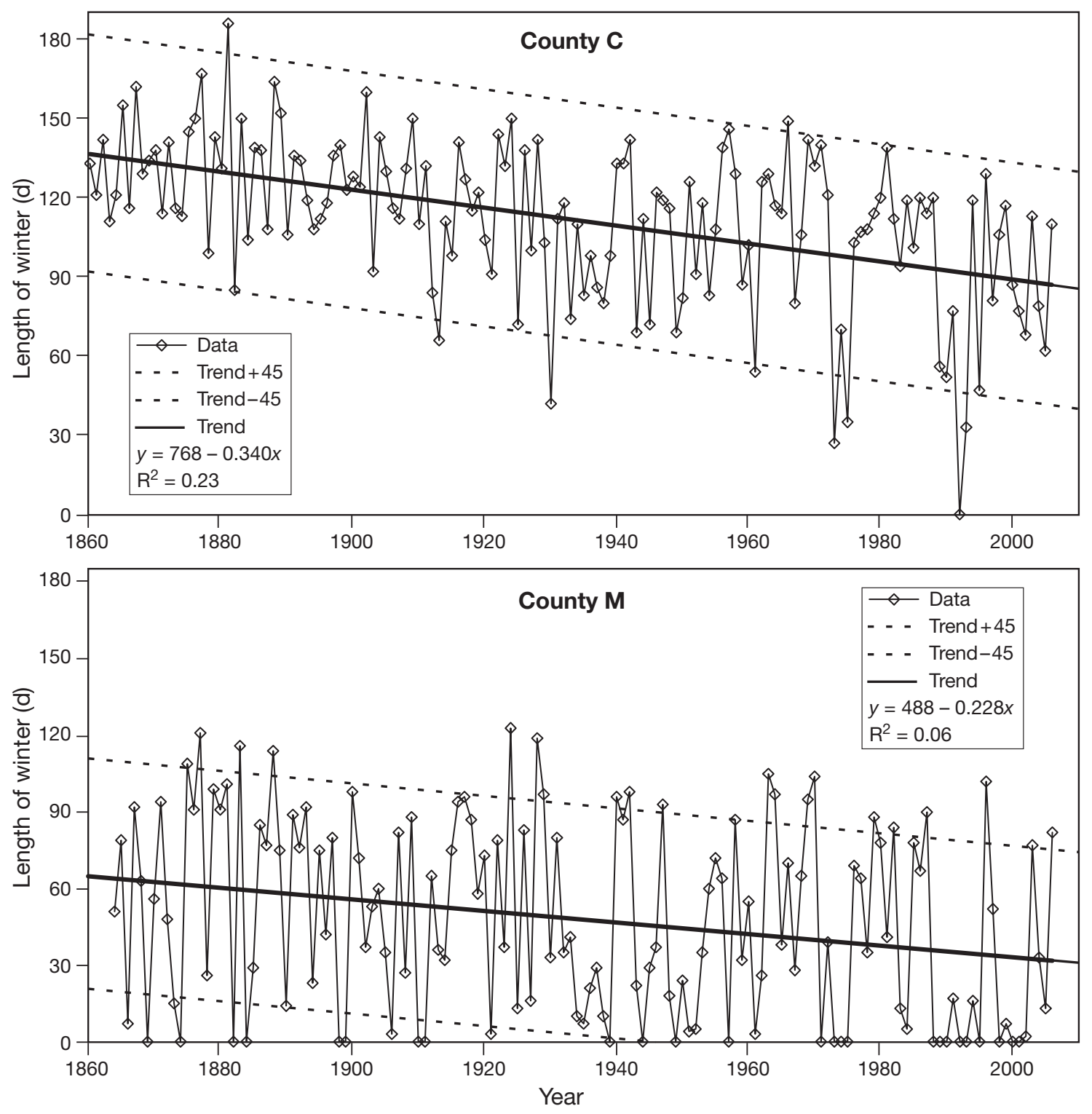

Fig. 2. Length of winter in County C (Uppsala; upper panel) and County M (Lund; lower panel). The trends +45 and -45 are in days

The southern decrease can at least partly be an artefact, since it is not possible to get a short winter if the trend value is 45 or less (Fig. 2, lower panel). Long winters have increased during the last period (1960 to 2006).

\subsection{Winter wheat yields}

Yields have increased considerably since 1866; from about 1500 to $5000-7000 \mathrm{~kg} \mathrm{ha}^{-1}$ today (examples in Fig. 5). Especially, there has been an upward trend since 1960. Third-order polynomials describe the development fairly well-on average, across all counties the explained variance $\mathrm{R}^{2}$ is 0.80 .
Table 2. Frequencies of winters deviating at least $45 \mathrm{~d}$

\begin{tabular}{|lcccc|}
\hline & \multicolumn{5}{c|}{ Frequency (\%) } \\
\cline { 2 - 5 } & South & Central & North & All counties \\
\hline Short winters & & & & \\
$1866-1912$ & 23.4 & 9.5 & 0.8 & 12.5 \\
$1913-1959$ & 14.0 & 12.2 & 7.1 & 11.8 \\
$1960-2006$ & 12.3 & 11.0 & 9.2 & 11.1 \\
$1866-2006$ & 16.6 & 10.9 & 5.8 & 11.8 \\
Long winters & & & & \\
$1866-1912$ & 11.1 & 5.2 & 2.3 & 6.6 \\
$1913-1959$ & 13.2 & 3.3 & 0.0 & 6.0 \\
$1960-2006$ & 20.9 & 6.1 & 2.8 & 10.4 \\
$1866-2006$ & 15.0 & 4.9 & 1.7 & 7.7 \\
\hline
\end{tabular}


There are considerable deviations from the trends. Since the deviations in kilogram per hectare, on average, increase with time, relative deviations (percent in relation to the trend values) were used in the analysis. Fig. 6 shows the yields detrended in this way for the same counties as in Fig. 5; it is evident that the changes in the methods to collect yield data have not caused jumps in the yield variability.

Deviations exceeding $\pm 25 \%$ were chosen arbitrarily for further studies. The frequencies of both low and high harvest yields increase with latitude (Fig. 7). Overall, such deviations have occurred about once every 5 yr $(19.7 \%)$ in a county, with about the same frequency for both low- and high-yielding years (Table 3). The frequencies are more than twice as high in the north as in the south. However, in the period from 1913 to 1959 there was about the same frequency of good harvests. Poor harvest yields were frequent in the 1913 to 1959 period, while the 1960 to 2005 period is distinguished by low frequencies.

\subsection{Length of winter and yield}

Plots of yield deviations versus length of winter deviations for the 3 clusters (Fig. 8) show a considerable scatter, but the trend lines are significant at the $0.1 \%$ level for all individual counties. Table 4 gives the slopes of the regression lines, as well as the coefficients of determination. On average, the slope is $-0.27 \%$ yield deviation per winter day deviation over the whole time period from 1866 to 2006, but the slopes increase from -0.14 in the south to -0.44 in the north, i.e. increasing sensitivity of yield in relation to deviations in length of winter. However, there are differences between the 3 time periods. The sensitivity was much higher from 1913 to 1959. The relations are weakest for the last period, especially for the south.

Fig. 9 and Table 5 show the deviations in length of winter between low and high harvest yielding years. On average, for the whole time period, the difference in length of winter is $50 \mathrm{~d}$, but it ranges between almost 2 mo in the south and $1 \mathrm{mo}$ in the north. The south to north trend is obvious only during the first 2 periods. Another difference is that the variation in length of winter was larger during the 1913 to 1959 period.

\section{DISCUSSION}

The regressions for yields of winter wheat Triticum aestivum over time have shown that the intercept at the statistical breaking-point in 1913 differs little, so the average level of yields before 1913 is valid in relation to the following period. However, the variability (frequency of harvests exceeding $\pm 25 \%$ of the trend) was smaller from 1866 to 1912 compared to from 1913 to 1959 (Table 3). This can be interpreted as if the variability was underestimated in the early statistics. On the other hand, the period 1913 to 1959 was influenced by the shortage of fertilizers during the 2 World Wars and also by the warm years of the 1930s and the cold

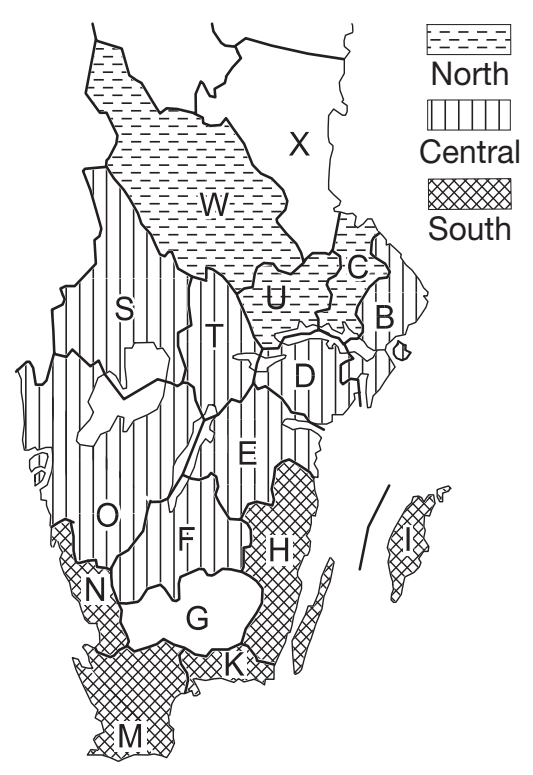

Fig. 3. Division of counties (north, central, and south) according to the cluster analysis of deviations in length of winter
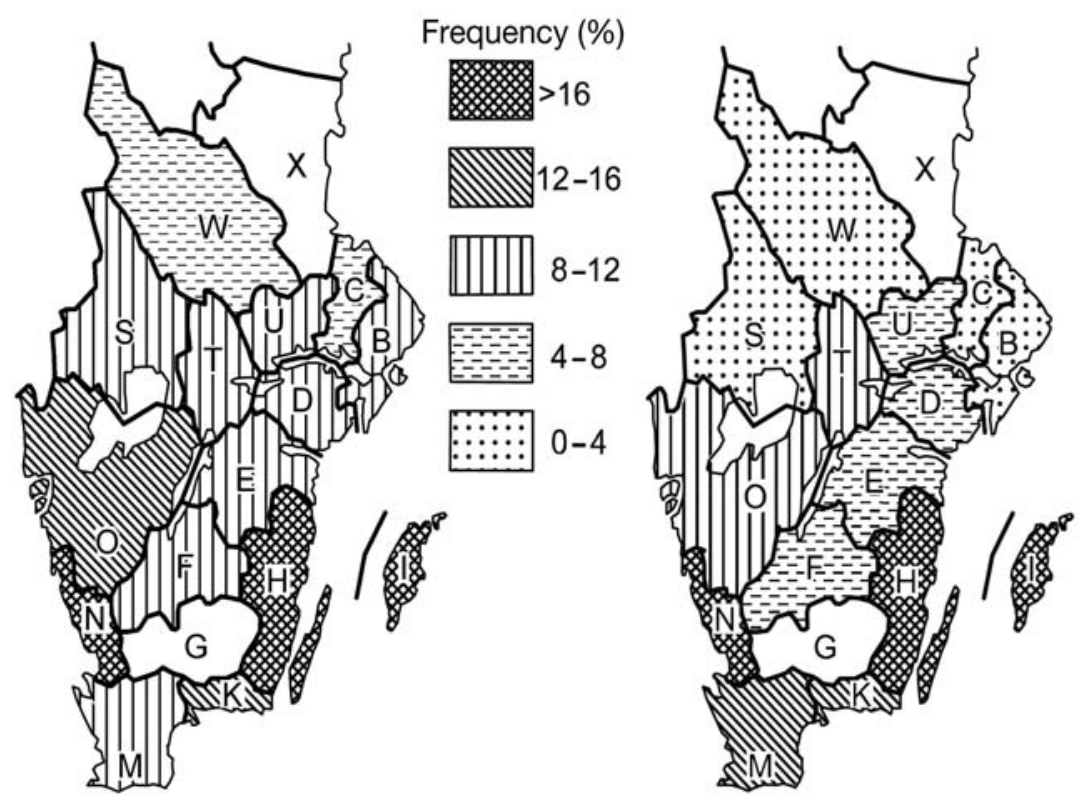

Fig. 4. Frequencies (\%) of winters shorter (left panel) and longer (right panel) than the trend from 1866 to 2006 

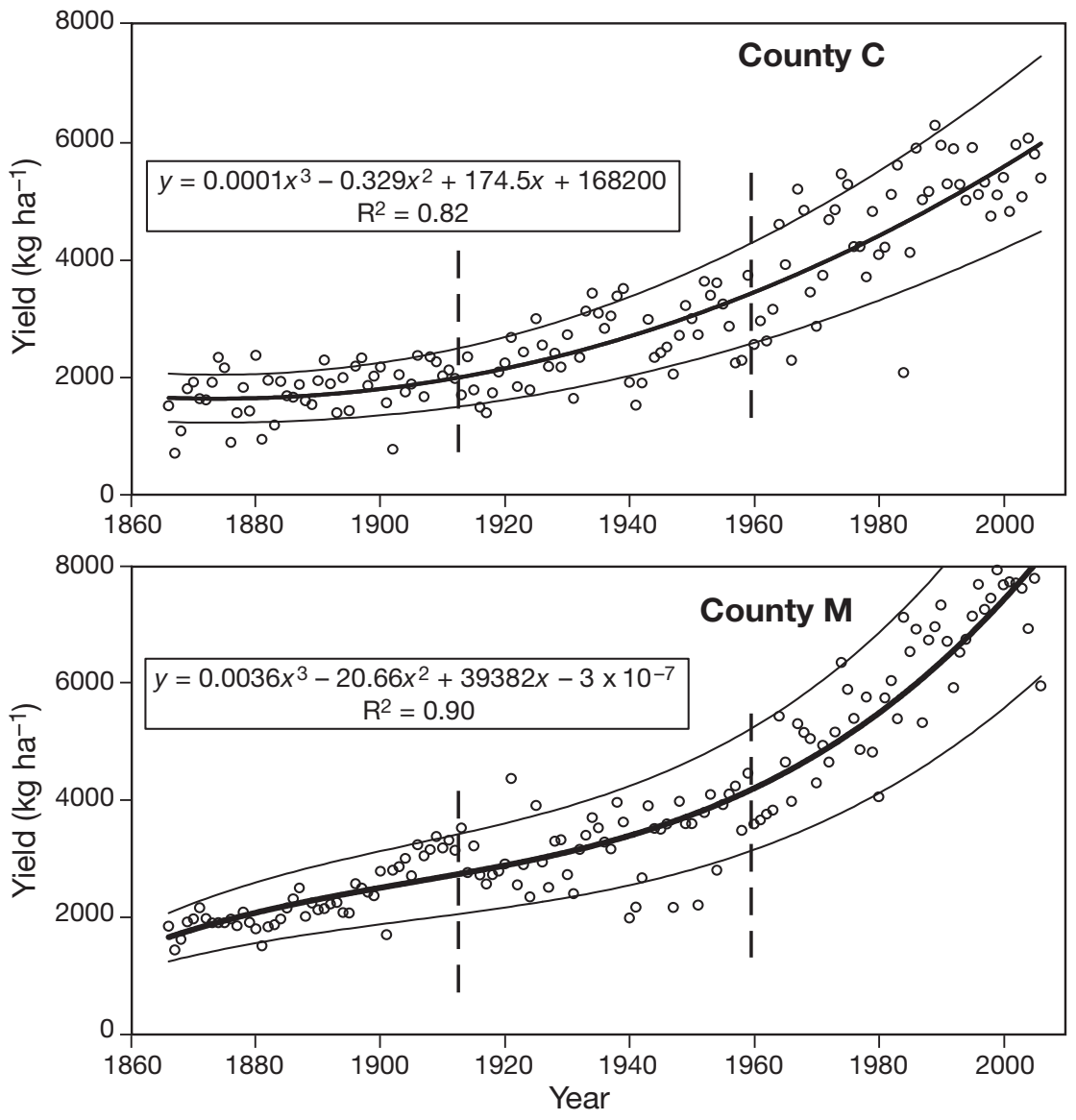

Fig. 5. Triticum aestivus. Yearly yields of winter wheat in Counties C (Uppsala; upper panel) and $M$ (Lund; lower panel). The vertical, dashed lines mark the 3 statistical periods. The curve in the middle is the 3 -order polynomial trend and the outer curves are $\pm 25 \%$ deviations from trend
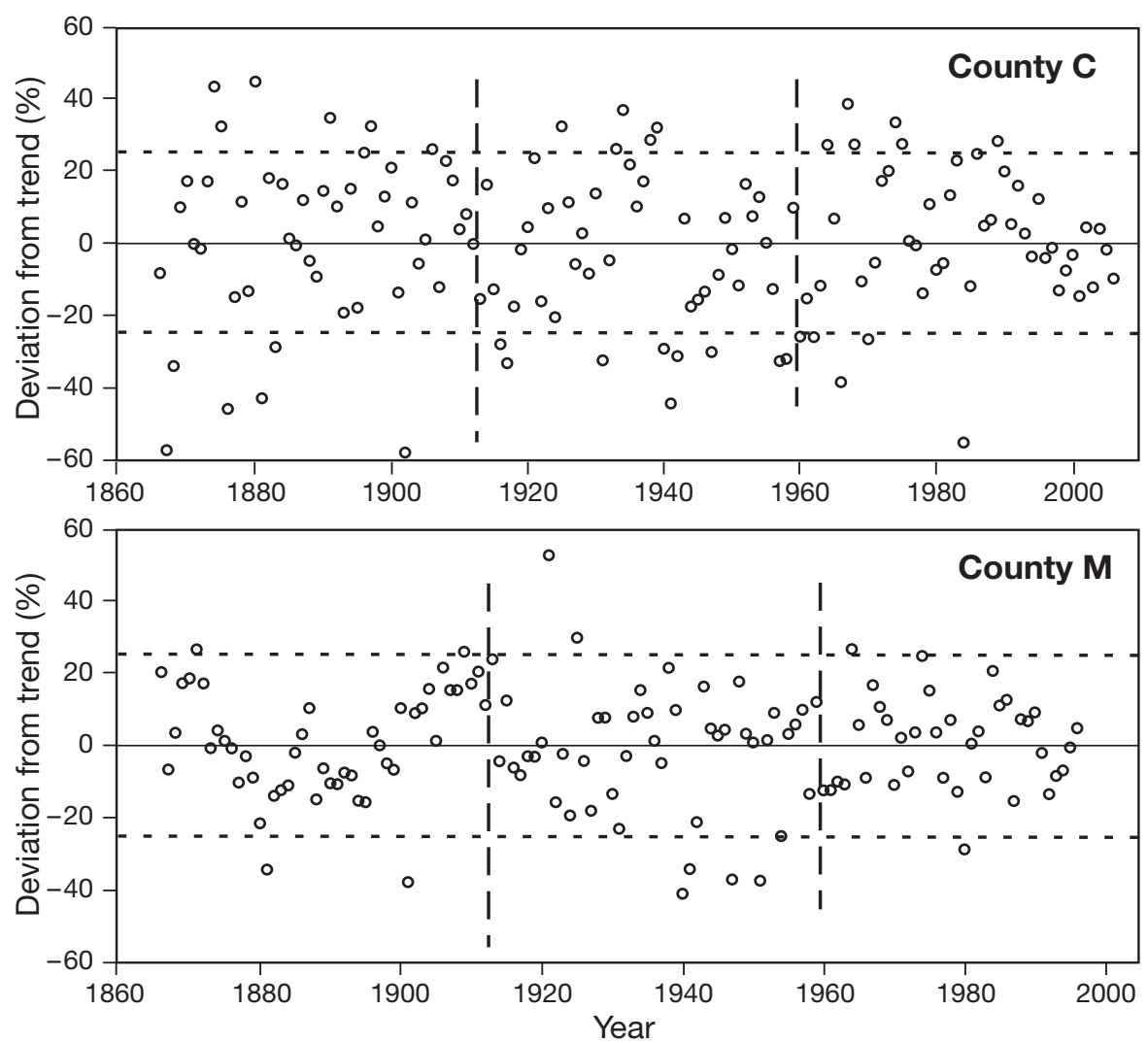

Fig. 6. Triticum aestivum. Detrended relative yields for the same counties as in Fig. 5. The horizontal, dashed lines ark $\pm 25 \%$ deviations 


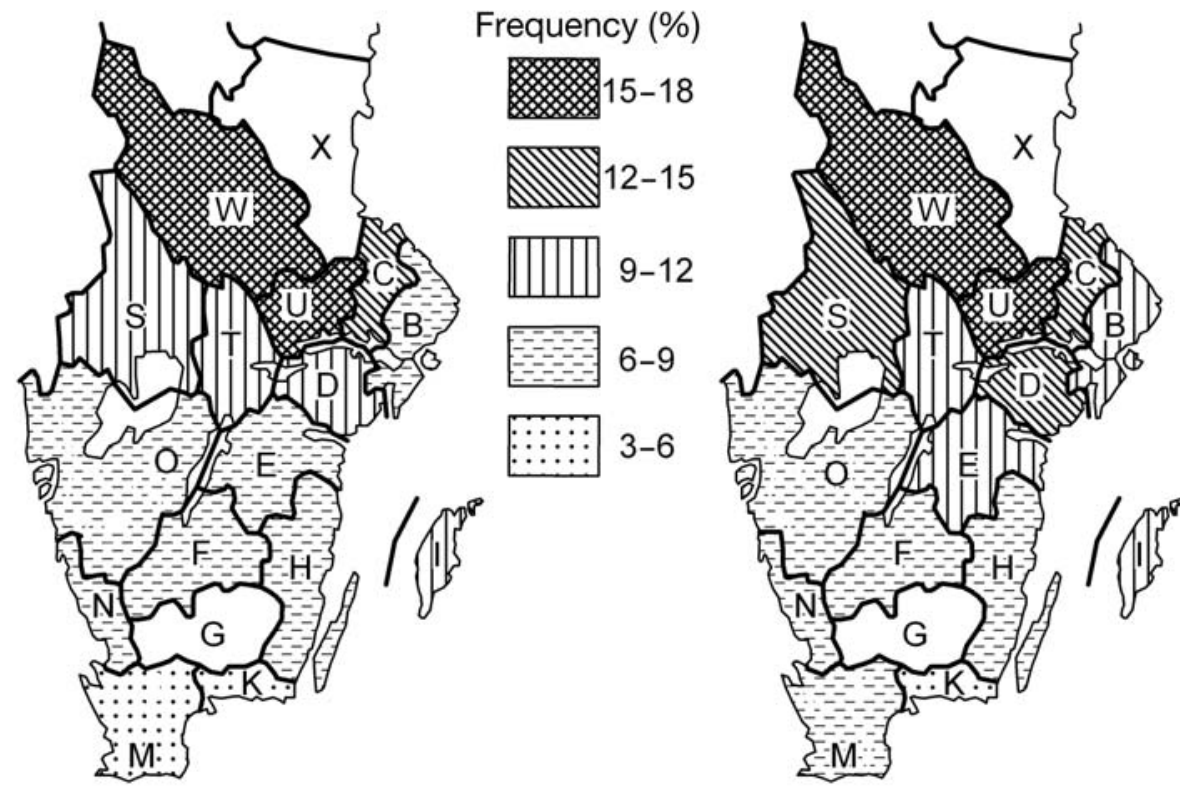

Fig. 7. Triticum aestivum. Frequencies of yields lower (left panel) and higher (right panel) than the trend from 1866 to 2006

Table 3. Triticum aestivum. Frequencies of yields deviating at least $25 \%$

\begin{tabular}{|lcccc|}
\hline & \multicolumn{5}{c}{ Frequency (\%) } \\
\cline { 2 - 5 } & South & Central & North & All counties \\
\hline Good harvests & & & & \\
$1866-1912$ & 4.3 & 6.4 & 17.9 & 8.0 \\
$1913-1959$ & 10.2 & 10.6 & 9.9 & 10.4 \\
$1960-2006$ & 5.7 & 8.3 & 19.7 & 9.4 \\
$1866-2006$ & 6.6 & 8.5 & 15.4 & 9.2 \\
Bad harvests & & & & \\
$1866-1912$ & 5.6 & 8.9 & 15.0 & 9.0 \\
$1913-1959$ & 12.3 & 15.8 & 21.3 & 15.7 \\
$1960-2006$ & 3.5 & 6.3 & 11.1 & 6.2 \\
$1866-2006$ & 7.3 & 10.4 & 16.2 & 10.5 \\
\hline
\end{tabular}

years of the 1940s. New high-yielding, but less hardy, wheat varieties may also have contributed to the increased variability, as well as increased wheat cultivation on less suitable soils. After 1960, the variability sank to the same level as before 1913, but with a decreasing trend (Fig. 5). In comparison, Calderini \& Slafer $(1998,1999)$ found that the variability had been about the same over the whole period, possibly with an increase during the last decade in high-yielding countries. The question is then: Does this decrease in variability in Sweden depend on climate? Table 2 shows that the frequencies of short winters have been about the same over the years, while the frequencies of long winters increased during the 1960-2006 period. Although the total variability in length of winter has increased, the variability of yields has decreased.
Perhaps this can be explanied by winter wheat varieties that are not so sensitive to the length of winter or perhaps the concentration of Swedish agriculture to the best soils reduces the influence of winters that are longer than usual.

Frequencies of both low- and high-yielding harvests are increasing towards the north. It seems reasonable that the response to differing climatic conditions will be greater closer to the northern border. On the other hand, the frequencies of winters deviating $>45 \mathrm{~d}$ are lower towards the north. This means that even small deviations of the length of winter are important in the northern counties, while the more frequently occurring anomalous winters in the south do not have the same importance. Contributing factors could be that winters in southern Sweden, especially along the coasts, are not far below the freezing point, that cyclonic circulations alternating with blocking highs give intermittent vernalization (Robertson et al. 1996) and that photoresponse in the absence of snow can also have an influence at sub-zero temperatures (Gonzalez et al. 2002). In the northern counties there are, in general, continuous periods, with temperatures below freezing and a lasting snow cover.

Regressions of deviating length of winter and yield deviations show that short winters give higher yields (Fig. 8, Table 4). The highly significant regression coefficients increase towards the north, i.e. yields are more sensitive to changes in length of winters northwards. This is in accordance with the results of frequencies of anomalous winters and yields discussed in the previous paragraph. The least sensitivity to the length of winter has been noted for the period 1960 to 2005, which can be interpreted to mean that other factors (for instance availability of water and/or concentration to better soils) are now more essential than in earlier times for the high-yielding wheat varieties used today. Contrary to this, the sensitivity to the length of winter was great during the period 1913-1959, which was distinguished by a growing share of higher yielding wheat varieties and increasing areas with wheat, often grown on soils that earlier were not considered suitable for wheat cultivation.

Moreover, the difference in the length of winter, in years with anomalous positive and negative yields, 

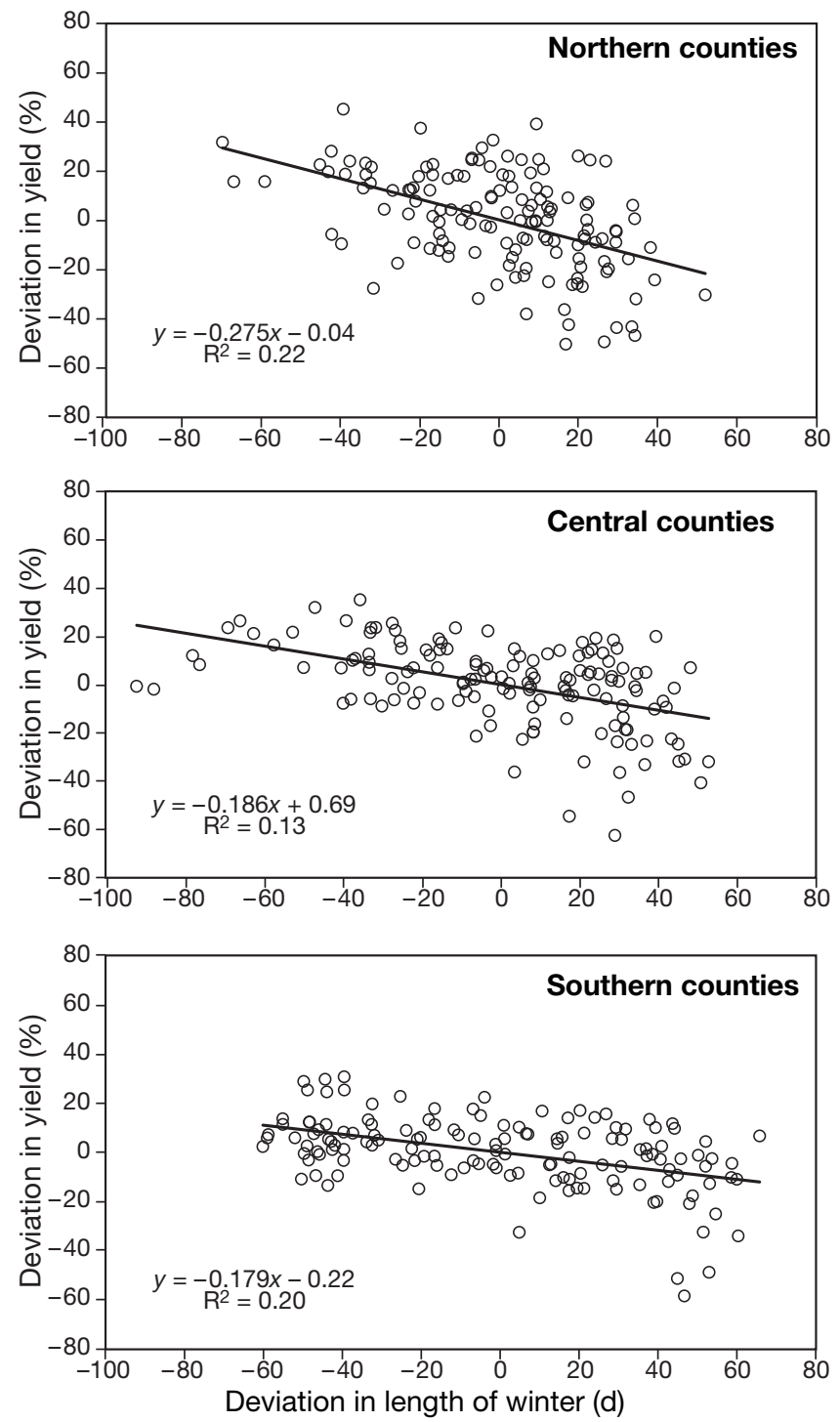

Fig. 8. Triticum aestivum. Deviations of yields in relation to deviations in length of winter from 1866 to 2006 for north, central and south regions

respectively, decreases from $60 \mathrm{~d}$ in the south to only $29 \mathrm{~d}$ in the north, thus stressing the importance of the climate conditions close to the northern border of winter wheat cultivation area as noted earlier.

In their regression analysis of agricultural experiments all over the UK, Landau et al. (1998) found $\mathrm{R}^{2}=$ 0.32 , based on 17 selected variables including rainfall, radiation and temperatures. Seven of the variables represented conditions during the colder half of the year, October to March, thus explaining half of the variance. Maximum temperature in January alone explained $9 \%$ of the variance. The regression model by Olesen et al. (2000) from 7 research stations in Denmark also emphasised the importance of winter condi-
Table 4. Relation between deviations in length of winter and winter wheat yield. ${ }^{*},{ }^{* *}$ and ${ }^{* * *}$ : significant at 5,1 and $0.1 \%$ level, respectively

\begin{tabular}{|lcl|}
\hline & Slope of regression $\left(\% \mathrm{~d}^{-1}\right)$ & $\mathrm{R}^{2}$ \\
\hline South & & \\
$1866-1912$ & -0.14 & $0.27^{* * *}$ \\
$1913-1959$ & -0.35 & $0.36^{* * *}$ \\
$1960-2006$ & -0.08 & $0.08^{*}$ \\
$1866-2006$ & -0.14 & $0.21^{* * *}$ \\
Central & & \\
$1866-1912$ & -0.18 & $0.27^{* * *}$ \\
$1913-1959$ & -0.41 & $0.36^{* * *}$ \\
$1960-2006$ & -0.22 & $0.08^{*}$ \\
$1866-2006$ & -0.18 & $0.21^{* * *}$ \\
North & & \\
$1866-1912$ & -0.52 & $0.24^{* * *}$ \\
$1913-1959$ & -0.47 & $0.34^{* * *}$ \\
$1960-2006$ & -0.38 & $0.27^{* * *}$ \\
$1866-2006$ & -0.42 & \\
All counties & & \\
$1866-1912$ & -0.22 & $0.26^{* * *}$ \\
$1913-1959$ & -0.44 & $0.41^{* * *}$ \\
$1960-2006$ & -0.18 & $0.26^{* * * *}$ \\
$1866-2006$ & -0.27 & \\
\hline
\end{tabular}

tions on winter wheat yield. Of the 6 selected variables, 3 were temperatures in the cooler part of the year, explaining $42 \%$ of the variance with cultivation year, i.e. genetic improvements, accounting for $>15 \%$; radiation in April, 12\%; and precipitation in July, 8\%. The 3 temperature variables together explained $7 \%$ of the variation. Furthermore, correlations from $>100 \mathrm{yr}$ of data from an experimental station in southern Eng-

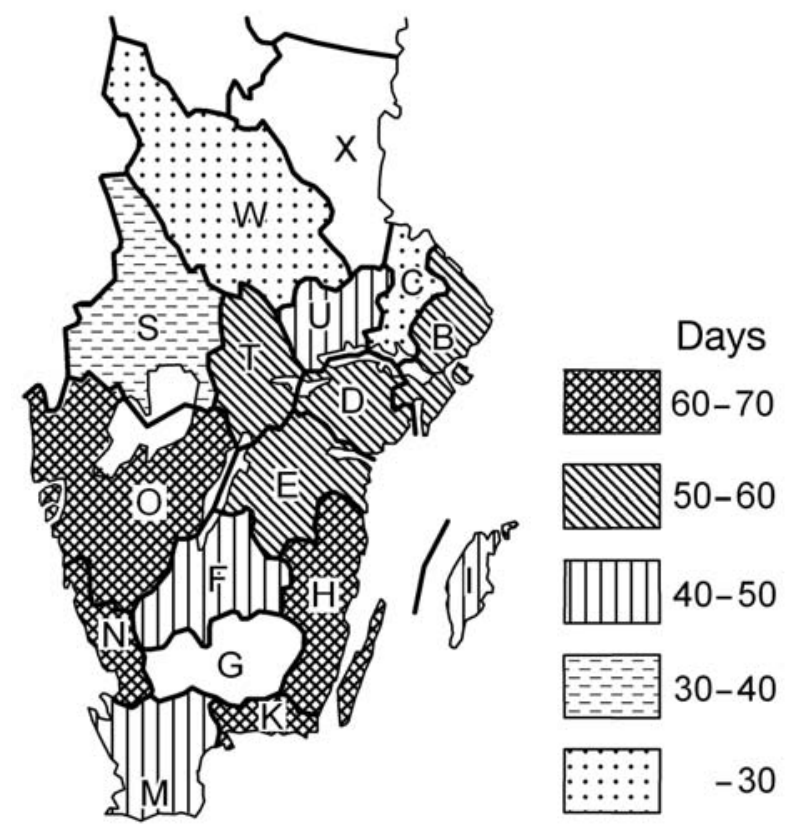

Fig. 9. Difference in length of winter between low (less than $-25 \%$ ) and high (greater than $25 \%$ ) winter wheat yields from 1866 to 2006 
Table 5. Change in length of winter when winter wheat yield deviates at least $\pm 25 \%$

\begin{tabular}{|c|c|c|c|c|}
\hline & \multicolumn{4}{|c|}{$\begin{array}{l}\text { Difference in winter length between } \\
\text { low and high harvest yields (d) }\end{array}$} \\
\hline & South & Central & North & All counties \\
\hline 1866-1912 & 61 & 45 & 26 & 46 \\
\hline $1913-1959$ & 68 & 60 & 48 & 60 \\
\hline $1960-2006$ & 46 & 50 & 42 & 46 \\
\hline $1866-2006$ & 60 & 51 & 29 & 50 \\
\hline
\end{tabular}

land (Chmielewski \& Potts 1995) corresponded to maximum explained variance of $8 \%$ for any single variable. It can also be noted that temperatures were more important during the colder 6 mo than in the warmer $6 \mathrm{mo}$, but the opposite was valid for precipitation. The survey above of explained variance structure from other studies shows that winter conditions are as important as summer conditions to yields. Finally, Cantelaube et al. (2004) found that Sweden had the highest explained variance $\left(\mathrm{R}^{2}=0.24\right)$ of the then 15 states of the European Union in a comparison between PC1 in the EOF analysis of wintertime $500 \mathrm{hPa}$ geopotential height and winter wheat yields. Thus, except for the last study, it has been shown that no single climate variable explains $>12 \%$ of yield variations. Therefore, the $26 \%$ explained variance between climate and yields found in the present study is high.

The results of this study correspond to other observational studies of time series of yields in areas with cold winters (Enquist 1929, Landau et al. 1998, 2000, Olesen et al. 2000), i.e. cold winters give less yield. In contrast, the warmer southern England (Chmielewski \& Potts 1995) and the much warmer Georgia (United States) areas showed increasing yields with cool winters (Alexandrov \& Hoogenboom 2001). Thus, it seems as if Sweden and other areas with winter temperatures below the optimum vernalization temperatures of 5 to $6^{\circ} \mathrm{C}$ (Rawson et al. 1998, Porter \& Gawith 1999, Yan \& Hunt 1999) benefit by short winters, while the opposite is valid for areas above this limit. Vernalization at low temperatures needs more time (Rawson et al. 1998, Brooking \& Jamieson 2002). Furthermore, long winters restrict the growing season and, as a result, long and cold winters give smaller yields.

However, field experiments with enhanced temperatures and $\mathrm{CO}_{2}$ concentrations show that decreasing yields depend on a warmer climate if no fertilising effect by increasing $\mathrm{CO}_{2}$ is included (Batts et al. 1997). Crop modelling studies (Harrison \& Butterfield 1996, Brown \& Rosenberg 1999, Wassenaar et al. 1999, Alexandrov \& Hoogenboom 2000a,b, Reilly et al. 2003) show the same result, and this is also the case in highlatitude areas such as Denmark (Olesen et al. 2000) and Scotland (Peiris et al. 1996).

\section{CONCLUSIONS}

Over the many years considered in this investigation the methods of collecting both climate and yield data have changed several times; however, no obvious discontinuities have been noted. Furthermore, since deviations from trends are used, these methodological differences are considered to be of minor importance.

From a climate perspective, the length of winter varies more in southern Sweden, where conditions are more dependent on winter temperatures near the freezing point. Warm spells during the winter probably reduce the effect of long winters in the south, while more continuous periods of cold prevail in the north. About 1 yr in 5 had a variation in the length of winter exceeding $\pm 45 \mathrm{~d}$.

In terms of winter wheat yields in Sweden, on average, large yield deviations (at least $\pm 25 \%$ ) have also occurred in about $1 \mathrm{yr}$ in 5, but more often in the northern counties. The period from 1913 to 1959 had a higher frequency of deviating harvests, but not in winter length deviations.

Regressions reveal highly significant correlations between yield variations and length of winter variations showing that short winters typically give higher yields. The influence of length of winter was greater between 1913 and 1959 than in the other 2 periods. The overall explained variation between climate and wheat yields is $26 \%$, which is high for a single climatic variable. Regression coefficients increase northward, which means that a given change in the length of winter is more important to yields in the north. For the wheat growing areas in Sweden, the difference in the length of winter is $50 \mathrm{~d}$ for harvests, with roughly $25 \%$ above average compared to $25 \%$ below average, and with a higher number of days in the north.

The positive effect of mild and short winters on yields is confirmed by other studies in areas with winter temperatures below the optimum vernalization temperature of 5 to $6^{\circ} \mathrm{C}$, while crop models show decreasing yields with higher temperatures.

Acknowledgements. Thanks to Associate Professors Jörgen Bogren and Torbjörn Gustavsson for important comments on an earlier version of this study. Comments from anonymous reviewers were also appreciated. The English text was checked by Mrs Britt-Marie Lennersand.

\section{LITERATURE CITED}

Alexandrov VA, Hoogenboom G (2000a) The impact of climate variability and change on crop yield in Bulgaria. Agric For Meteorol 104:315-327

Alexandrov VA, Hoogenboom G (2000b) Vulnerability and adaption assessments of agricultural crops under climate change in the southeastern USA. Theor Appl Climatol 
$67: 45-63$

Alexandrov VA, Hoogenboom G (2001) Climate variation and crop production in Georgia, USA, during the twentieth century. Clim Res 17:33-43

Ångström A (1938) Lufttemperatur och temperaturanomalier i Sverige 1901-30. Rep No. 2, Meddelanden från Statens meteorologisk-hydrografiska anstalt, Stockholm

Batts GR, Morison JIL, Ellis RH, Hadley P, Wheeler TR (1997) Effects of $\mathrm{CO}_{2}$ and temperature on growth and yield of crops of winter wheat over four seasons. Eur J Agron 7: 43-52

Bourke A, Rosini E (1985) Impact of climatic fluctuations on European agriculture. In: Flohn H, Fantechi R (eds) The climate of Europe: past, present and future. D. Riedel Publishing, Dordrecht, p 269-314

Brooking IR, Jamieson PD (2002) Temperature and photoperiod response of vernalization in near-isogenic lines of wheat. Field Crops Res 79:21-38

Brown RA, Rosenberg NJ (1999) Climate change impacts on the potential productivity of corn and winter wheat in their primary United States growing regions. Clim Change 41: 73-107

> Calderini DF, Slafer GA (1998) Changes in yield and yield stability in wheat during the 20th century. Field Crops Res 57:335-347

Calderini DF, Slafer GA (1999) Has yield stability changed with genetic improvement of wheat yield? Euphytica 107:51-59

Cantelaube P, Terres JM, Doblas-Reyes FJ (2004) Influence of climate variability on European agriculture-analysis of winter wheat production. Clim Res 27:135-144

> Chmielewski FM, Potts JM (1995) The relationship between crop yields from an experiment in southern England and long-term climate variations. Agric For Meteorol 73:43-66

Ekholm N (1914) Calcul de la température moyenne mensuelle de l'air aux stations météorologiques Suédoises. Rep No. 56, Bihang till meteorologiska iakttagelser, Stockholm

Enquist F (1929) Studier över samtidiga växlingar i klimat och växtlighet. (Studies of contemporary changes in climate and vegetation.) Sven Geogr Arsb 1929:7-50

Fournier A (2003) Atmospheric energetics in the wavelet domain. II. Time-averaged observed atmospheric blocking. J Atmos Sci 60:319-338

Gonzalez FG, Slafer GA, Miralles DJ (2002) Vernalization and photo-periodic responses in wheat pre-flowering reproductive phases. Field Crops Res 74:183-195

Hannerberg D (1971) Svenskt agrarsamhälle under 1200 år. Läromedelsförlagen, Stockholm

Harding RJ (1978) The variation of the altitudinal gradient of temperature within the British Isles. Geogr Ann Ser A 60:43-49

Harding RJ, Green FHW (1980) The altitudinal gradients of air temperature in southern Norway. Geogr Ann Ser A 62: 29-36

Harrison PA, Butterfield RE (1996) Effects of climate change on Europe-wide winter wheat and sunflower productivity. Clim Res 7:225-241

Höijer E (1921) Tabeller till belysning av det svenska jordbrukets utveckling 1871-1919. Jämte anmärkningar. Tulloch Traktatkommitténs utredningar och betänkanden V, Stockholm

Laaksonen K (1976) The dependence of mean air temperature upon latitude and altitude in Fennoscandia (1921-50). Ann Acad Sci Fenn Ser A 119:3-19

Editorial responsibility: Gregory Jones,

Ashland, Oregon, USA
Lägnert F (1949) Veteodlingen i södra och mellersta Sverige. (Wheat cultivation in southern and Central Sweden). LT:s förlag, Stockholm

> Landau S, Mitchell RAC, Barnett V, Colls JJ, Craigon J, Moore KL, Payne RW (1998) Testing winter wheat simulation models' predictions against observed UK grain yields. Agric For Meteorol 89:85-99

Landau S, Mitchell RAC, Barnett V, Colls JJ, Craigon J, Payne RW (2000) A parsimonous, multiple-regression model of wheat yield response to environment. Agric For Meteorol 101:151-166

Lejenäs H (1985) Long-term variations of atmospheric blocking in the northern hemispere. J Meteorol Soc Jpn 73: 79-89

Medin K (1999) Statistiska centralbyrån tar över-allmän jordbruksstatistik 1865-1920. In: Jorner U (ed) Svensk jordbruksstatistik 200 år. Statistiska centralbyrån, Halmstad, p 49-85

Moberg A, Bergström H (1997) Homogenization of Swedish temperature data. III. The long temperature records from Uppsala and Stockholm. Int J Climatol 17:667-699

$>$ Olesen JE, Jensen T, Petersen J (2000) Sensitivity of fieldscale winter wheat production in Denmark to climate variability and climate change. Clim Res 15:221-238

Olofsson PO (1999) Skördestatistik med objektiva metoderskördeuppskattningar 1961-1997. In: Jorner U (ed) Svensk jordbruksstatistik 200 år. Statistiska centralbyrån, Halmstad, p 163-196

Peel MD, Riveland N (1997) Winter wheat production in North Dakota. Extension Bulletin 33, North Dakota State University, Fargo, ND

Peiris DR, Crawford JW, Grashoff C, Jefferies RA, Porter JR, Marshall B (1996) A simulation study of crop growth and development under climate change. Agric For Meteorol 79:271-287

Porter JR, Gawith M (1999) Temperatures and the growth and development of wheat: a review. Eur J Agron 10:23-36

Raab B, Vedin H (eds) (1995) Climate, lakes and rivers. National Atlas of Sweden, Stockholm

Rawson HM, Zajac M, Penrose LDJ (1998) Effect of seedling temperature and its duration on development of wheat cultivars differing in vernalization response. Field Crops Res 57:289-300

Reilly J, Tubiello F, McCarl B, Abler D and others (2003) U.S. agriculture and climate change: new results. Clim Change 57:43-69

> Robertson MJ, Brooking IR, Ritchie JT (1996) Temperature response of vernalization in wheat: modelling the effect on the final number of mainstem leaves. Ann Bot (Lond) 78:371-381

Stein O (2000) The variability of Atlantic-European blocking as derived from long SLP time series. Tellus Ser A Dyn Meteorol Oceanogr 52:225-236

Svensson J (1965) Jordbruk och depression 1870-1900. Cavefors förlag, Malmö

Trewartha GT (1982) The Earth's problem climate. Wisconsin University Press, Madison, WI

Wassenaar T, Lagacherie P, Legros JP, Rounsevell MDA (1999) Modelling wheat yield responses to soil and climate variability at the regional scale. Clim Res 11:209-220

> Yan W, Hunt LA (1999) Reanalysis of vernalization data of wheat and carrot. Ann Bot (Lond) 84:615-619

Zetterberg O, Dalenius T, Bachér I, Sandelius M (1953) Provundersökningarna rörande ny skördeberäkningsmetod. Statistisk tidskrift 2:136-143

Submitted: September 5, 2006; Accepted: February 4, 2008

Proofs received from author(s): April 24, 2008 